\title{
EDITORIAL
}

\section{O pensamento crítico de Antonio Candido}

Escritor, crítico literário, sociólogo e professor, Antonio Candido (1918-2017) é um dos mais reconhecidos e prestigiados pensadores brasileiros. Foi um dos fundadores do Partido dos Trabalhadores - PT e sua militância de esquerda foi exercida na política e na crítica literária. Ao estrear como crítico na Folha da Manhã, em 1943, finalizou sua apresentação de princípios declarando a seguinte norma de conduta: "Se nem sempre é possível dizer tudo aquilo que se pensa, é sempre possível dizer apenas aquilo que se pensa. E é o que farei" ". Seu falecimento em maio de 2017, próximo de completar 100 anos de seu nascimento em 24/07/1918, foi lamentado por diferentes círculos intelectuais e políticos, e suscitou merecidas homenagens ao estudioso por parte da imprensa e de diversas instituições universitárias. A título de exemplo, podemos citar as seguintes revistas que, recentemente, dedicaram-lhe dossiê: Revista Contramão n. 3 (2017); Revista USP, n. 118 (2018); Revista Todas as Musas, n.1 (2018); Revista Atlântica n. 35 (2019).

Autor de livros fundamentais para os estudos sobre literatura e sociedade, como Formação da Literatura Brasileira: momentos decisivos (1959) e Os parceiros do Rio Bonito: estudo sobre o caipira paulista e a transformação dos seus meios de vida (1964), mas também de ensaios críticos relevantes, como "Dialética da malandragem" e "De cortiço a cortiço", a citação de seus textos nos trabalhos acadêmicos das áreas de ciências humanas e sociais tornouse, com certa frequência, exigência incontornável. Em entrevista publicada no dossiê "Antonio Candido e a formação da literatura brasileira", da Revista $O$ eixo e a roda, em 2011, ao ser instigado a realizar um balanço íntimo sobre a recepção crítica de seu Formação da literatura brasileira passados 50 anos da primeira edição, Antonio Candido destacou a falta de discussões sobre as análises, escolhas, filiações e articulações das obras e dos escritores ali realizadas, face

${ }^{1}$ CANDIDO, ANTONIO. Textos de intervenção: Antonio Candido. Seleção, apresentação e notas de Vinicius Dantas. São Paulo: Duas Cidades; Ed. 34, 2002. 
o interesse muito maior dos leitores pelos pressupostos presentes no "Prefácio" e na "Introdução".

Sem deixamos de reconhecer a existência de trabalhos importantes que se pautam pelo diálogo com o legado do estudioso, o presente dossiê da Revista Jangada, filiada ao Programa de Pós-graduação em Letras da Universidade Federal de Viçosa, teve por objetivo acolher trabalhos que tivessem em conta as análises críticas, os pressupostos teóricos e as perspectivas históricas da literatura e da cultura realizadas pelo saudoso professor. Buscou-se, sobretudo, a discussão do legado de Antonio Cândido em suas diversas facetas: crítico literário, ensaísta, historiador, sociólogo, militante. Como resultado, damos a publico um dossiê constituído de sete artigos e duas "conversas" (para usarmos a expressão preferida do professor Arnaldo Saraiva em lugar de entrevista), seguidos de um artigo e duas resenhas de temática variada.

Pesquisadores de diferentes instituições submeteram seus trabalhos, permitindo-nos ressaltar o alcance cada vez maior que a Revista Jangada tem obtido ao longo de seus seis anos de existência. O primeiro artigo, intitulado "A teoria de Antonio Candido e a formação da literatura australiana", de autoria de Déborah Scheidt, parte do conceito de "literatura como sistema", desenvolvido por Candido em Formação da literatura brasileira (1959), para pensar, em uma perspectiva comparatista, a formação da literatura australiana, propondo que a mesma tem início quando "as obras deixam de apresentar, direta ou indiretamente, características de literatura de viagens e passam a se dirigir principalmente a um público local”.

O segundo texto, intitulado "A crítica sociológica e dialética de Antonio Candido: entre o fato social e a expressão artística", de autoria de Fabrício Lemos da Costa e Sílvio Augusto de Oliveira Holanda, apresenta aspectos importantes desenvolvidos por Antonio Candido no volume Literatura e sociedade (1965), sobretudo a análise do romance Senhora (1875), de José de Alencar, retomando o modo como o crítico discutiu fatores condicionantes da estrutura interna da obra. Na sequência, temos o artigo "As várias faces de um crítico: recepção acadêmica de Antonio Candido em três congressos de Ciências Sociais (2005-2017)”, de Luis Gustavo de Paiva Faria e Victor Luiz Alves Mourão, constituindo-se em uma análise da recepção do legado do crítico literário por pesquisadores das Ciências Sociais, demonstrando as múltiplas apropriações desse legado.

O próximo texto, “Afetuosos abraços e saudades: cartas de Murilo Mendes e Antonio Candido", de Moema Rodrigues Brandão Mendes, debruça-se sobre as correspondências enviadas por Murilo Mendes a Antonio Candido e sua esposa Gilda de Mello e Souza. Trata-se de 18 mensagens datadas de 1958 a 1972, distribuídas em 16 cartas e 2 cartões, enviados por Murilo Mendes de Roma e Lisboa, atualmente, sob a guarda do Museu de Arte Murilo Mendes 
(MAMM), administrado pela Universidade Federal de Juiz de Fora (UFJF). O próximo artigo, "Antonio Candido leitor da poesia de João Cabral de Melo Neto", de autoria da professora Joelma Santana Siqueira (UFV), como o título sugere, analisa a recepção crítica da poesia de João Cabral de Melo Neto pelo crítico Antonio Candido, detendo-se com mais vagar na resenha crítica "Notas de crítica literária - Poesia ao Norte", publicada na Folha da Manhã em 13 de junho de 1943, constantemente recuperada pelos estudiosos da poesia cabralina.

O último artigo desse bloco intitula-se "Pelas veias de Antonio Candido: a literatura como fenômeno humanizador e fonte de transformação social", de autoria de Wilder Kleber Fernandes de Santana e Éderson Luís Silveira, busca estabelecer relações entre o pensamento crítico de Candido e o de outros estudiosos da literatura brasileira, cujos horizontes de produção e reflexão instigam a um processo de transformação social.

Em seguida, temos duas conversas. A primeira realizada entre o professor Dirceu Magri e a professora Joelma Siqueira, trata principalmente das contribuições de Antonio Candido reconhecidas por Magri para a sua formação acadêmica e para suas pesquisas embasadas no conceito de transferência cultural. A segunda, realizada entre Antonio Candido e o professor emérito da Universidade do Porto Arnaldo Saraiva (que, gentilmente, permitiu a publicação no presente dossiê), foi anteriormente publicada no livro Conversas com escritores brasileiros, Porto (2000), reeditado pela Editora Imprensa Universitária da Universidade Federal de Goiás em 2017. Nessa "conversa" é interessante observar, entre outros assuntos, a relação de Antonio Candido com a literatura portuguesa e com Portugal.

Em uma seção à parte ao dossiê, temos o ensaio "A margem da antologia em Ruy Belo", de Carolina da Silva Inacio, que analisa a obra País possível (1974), do poeta português Ruy Belo, como uma antologia, tendo em vista a organização dos poemas no interior do livro e a utilização dos elementos paratextuais que o compõem. Na sequência, temos uma resenha de Cristovam Bruno Gomes Cavalcante e Adalberto Luis Vicente sobre a recente tradução da obra Poemas (2018), de T. S, Eliot, realizada pelo professor Caetano Galindo, contraposta à tradução realizada em 2004 pelo poeta e crítico literário Ivan Junqueira. Interessante destacar aqui que em 1945, na já citada coluna "Notas de crítica literária" publicada na Folha da Manhã, Candido escreveu duas resenhas críticas dedicadas à poesia T.S. Eliot, quando o poeta inglês era pouco conhecido no Brasil. Por fim, apresentamos a resenha "Indícios do por vir desolador por meio da literatura em Depois do Futuro, de Franco Berardi”, escrita por Pedro Barbosa Rudge Furtado, sobre a tradução realizada por Regina Silva do volume Depois do futuro do filósofo italiano Franco Berardi. Dialogando com o texto "Literatura e subdesenvolvimento", de Antonio Candido, e textos de outros estudiosos, Furtado propõe que "a literatura, como 
podemos inferir via Berardi no contexto europeu e, principalmente, afirmar mediante Antonio Candido, no contexto brasileiro, antecipou a sensação de melancolia, proliferada mais tardiamente, de modo geral, na população média".

Finda esta breve apresentação do presente dossiê, desejamos a todos boas leituras e que novas reflexões questionadoras possam advir das ideias aqui presentes, interessadas sempre no diálogo e no debate frutíferos, capazes de contribuir para aprimorarmos o pensamento.

Diogo Tourino de Sousa (Departamento de Ciências Sociais/UFV) Gracia Regina Gonçalves (Departamento de Letras/UFV) Editores deste número 